LAHARS IN CRESCENT RIVER VALLEY, LOWER COOK INLET, ALASKA

By

James R. Riehle, Juergen Kienle, and Karen S. Emmel

GEOLOGIC REPORT 53

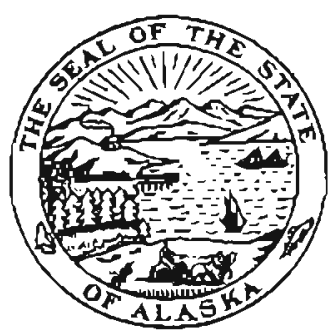




\section{STATE OF ALASKA}

Jay S. Hammond, Governor

Robert E. LeResche, Commissioner, Dept. of Nalural Resources

Geoffrey Haynes, Depuly Commissioner

Ross G. Schaff, State Geologist

Cover pholo: Redoubt Volcano in eruption, January 1966. (Taken by Jon Gardey from an airplane on north side of volcano looking west.)

Avallable from Alaska Division of Geological and Geophysical Surveys, P.O. Box 80007, College, 99708: 941 Dowling Ra., Archorage, 99502: P.O. Box 7438, Ketchikan, 99801; and 230 So. Franklín St. (Km 407), Juneau, 99801. 


\section{CONTENTS}

Page



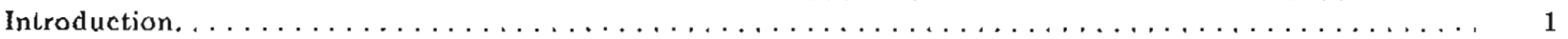



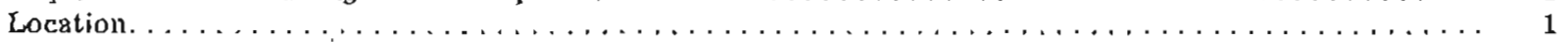



Interpretation of observations $\ldots \ldots \ldots \ldots$

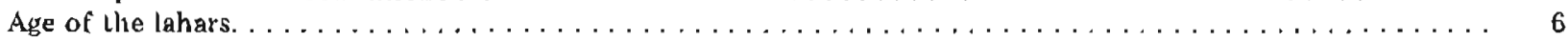



Potential hazards of lahars $\ldots \ldots \ldots \ldots \ldots$

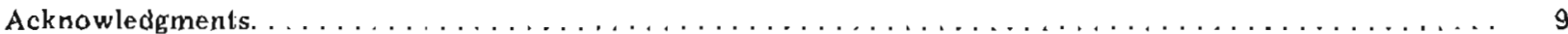

References cited $\ldots \ldots \ldots \ldots \ldots \ldots$

\section{FIGURES}

Figure 1. Photointerpretation map showing inferred extent of lahars in vicinity of Redoubt Volcano...... 2

2. Stereo pair showing morphology of lahar fan north of Lake Fork of Crescent River. . . . . . . . . . 3

3. Lahar deposits exposed in sea cliffs $6 \mathrm{~km}$ northeast of mouth of Crescent River. . . . . . . . . 5

4. Size distributions of lahars. . . . . . . . . . . . . . . . . . . . . . . . . . .

5. Inclined block of stratified sand and gravel enclosed in labar material in sea clif fs about $4 \mathrm{~km}$ northeast of mouth of Crescent River. . . . . . . . . . . . . . . . . . . . . . . . . . .

6. Generalized stratigraphic section at location of sea-cliff radiocarbon samples (fig. 1 ). . . . . . 


\title{
LAHARS IN CRESCENT RIVER VALLEY, LOWER COOK INLET, ALASKA
}

\author{
By James R. Riehle, ${ }^{1}$ Juergen Kienle, ${ }^{2}$ and Karen S. Emmel ${ }^{1}$
}

\begin{abstract}
Previously unrecognized lahars (volcanic mudflow deposits) occur in the Crescent River valley, west side of lower Cook Inlet. The lahars extend from glacier valleys on the southwest flank of Redoubt Volcano to the shore of Cook Inlet, a distance of more than $25 \mathrm{~km}$. Radiocarbon analyses of large pieces of wood suggest that the lowest labar exposed in sea cliffs was deposited about $3,500 \mathrm{yr}$ ago. The lahars may have been produced by events similar to the 1966 eruption of Redoubt Volcano, which resulted in mudflows and flooding of nearby Drift River. Although it has been several thou. sand years since lahars reached the shore of Cook Inlet vis the Crescent River val?ey, such eventis could occur again.
\end{abstract}

\section{INTRODUCTION}

A lahar is a flowing mixture of rock debris and water that originates on the llanks of a volcano or the deposit of such flows (Crandall, 1971, p. 3, following van Bemmelen, 1949). ${ }^{3}$ Lahars are either mudflows or debris Hows. Sharp and Nobles (1953) defined 'debris flow' as the deposit of a rapia tlowage of loose soll and rock debris mixed with water. Varnes (1958) restricted 'mudflow' to moving debris containing at least half sand-sized and finer material. Poor sorting of mudflow materials results in hlgh density and high transport competency, but there must be a fluid phase (claywater mixture) with sufficient strength and density to support the smaller granular constituents (Rodine, 1975). Each size range of granular constituents in turn supports the next larger range.

MudBows are more than 80 percent sediment during now: another type of now, called hyperconcentrated flow' is intermediate belween normal streamflow (less than 40 percent sediment) and mudflow (Beverage and Culbertson, 1964). Because the processes of transport are gradational from mudflow to normal streamtlow, lahar deposits may range from nonsorled deposits of mudflows to interbedded deposits of fluvial sand and gravel (Crandall, 1971, p. 5).

Lahars originate in many ways. Some form directly through volcanic activity, such as eruptions through a

\footnotetext{
${ }_{2}^{1}$ DGGS, Anchorage, A K 99501.

2 Geophysical Institute, Univorsity of Alaska, Faixbanks, AK 99701 .

${ }^{3}$ Latiar deposit' is used hereafter to omphasize the dislinction botween the process of flow and the resulting deposil.
}

crater lake, direct eruption or ejection of mud through volcanic vents, or avalanching of hot rock debris. Meltwater lahars originate by the eruption of lava, hot ash, and blocks onto snow or ice or by subglacial volcanic heating. Other lahars are only indirectly related to volcanic actlvity. Fallure of crater walls, for example, may occur at times other then during an enuption. Blankets of ash and puroice, which are common on flanks of active volcanoes, frequently slide and how when saturated during heavy precipitation. Volcanic rocks weakened by alteration around fumaroles and hot springs occasionally fail by sliding, resulting in lahars. Some volcanic landslides dam rivers; these dams later fail, generating floods and lahars. Among the most spectacular floods are "jökulhlaups," caused by subglacial volcanic heating, commonly observed in Iceland. These large floods are the result of the sudden release of meltwater stored in subglacial or englacial reservolrs (Crandall, 1971, p. 8-10; MacDonald, 1972, p. 170.81; Williams and McBirney, 1979, p. 171-78).

\section{DESCRIPTION AND INFERRED ORIGIN OF THE DEPOSITS}

\section{LOCATION}

Redoubt Volcano is an active, andesitic stratovolcano located $175 \mathrm{~km}$ west-southwest of Anchorage and $20 \mathrm{~km}$ inland from the west shore of Cook Inlet (Iig. 1). Four periods of activity have been recorded between the discovery of the volcano in 1778 by Captain James Cook (Beaglehole, 1967), and 1933 (Coats, 1950). Events in 1778, 1819, and 1933, when only 'smoke'4 was reported, were apparently minor. In 1902, however, an eruption spread ash about $200 \mathrm{~km}$ northeast to the towns of Knik, Hope, and Sunrise. ${ }^{5}$ The most recent activity occurred from 1966 to 1968 , when ash clouds reached heights of $13,500 \mathrm{~m}$ (Wilson and others, 1966; Wis on and Forbes, 1969).

The inferred extent of the Crescent River lahar deposits is based largely on photointerpretation (flg. 1). The surface morphology of the deposits is fanlike in the area east of Crescent Lake ( $\mathrm{fig} .2$ ) and adjacenl to Cook Inlet. The deposits are probably thickest in the fans and

\footnotetext{
4'Smoke' is frequently used in histaric recards, and refers to steam or steam and ash clouds.

5 Various articles in tha newspaper "The Alaskan" in March 1902.
} 


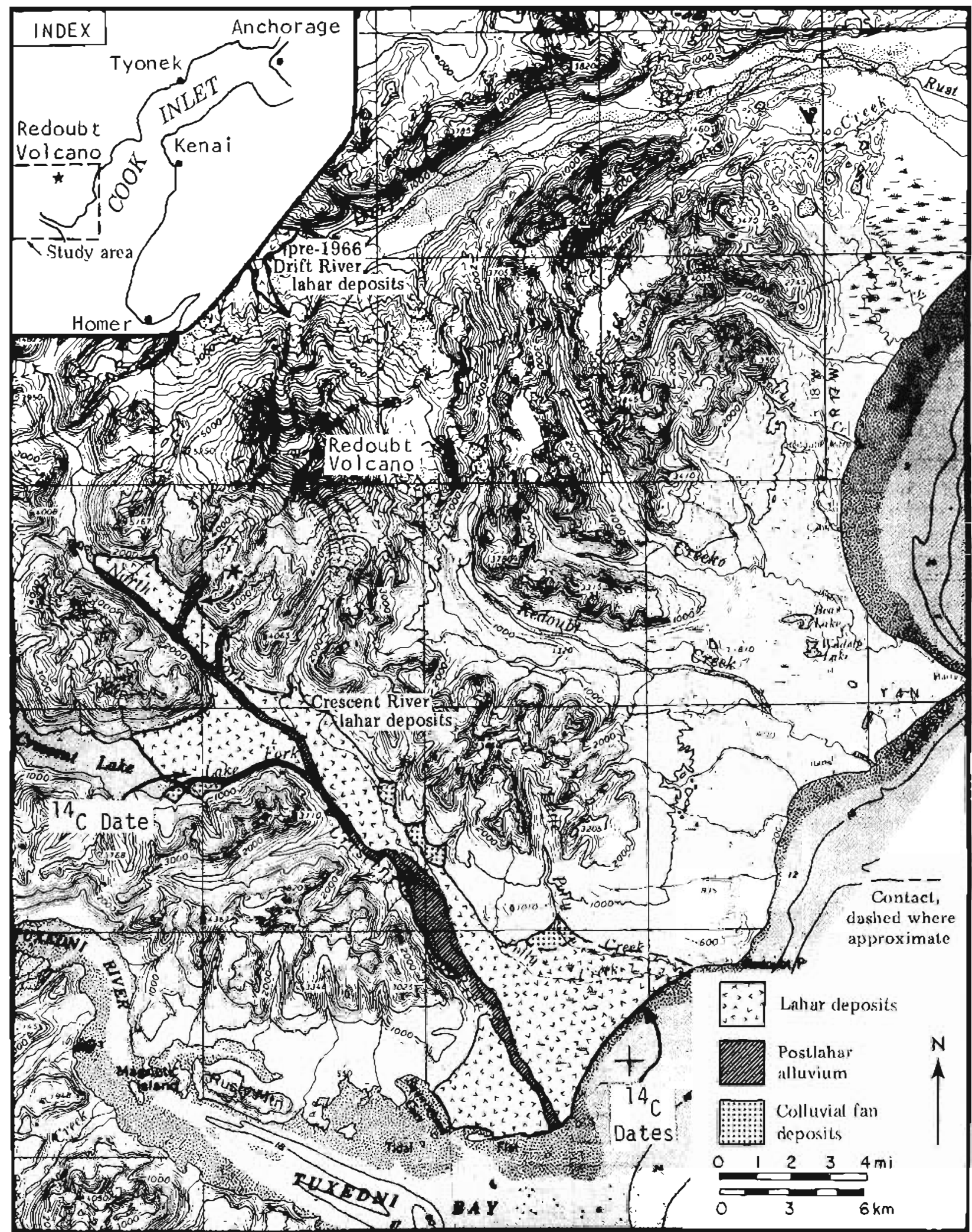

Figure 1. Pholoinlerpretation map showing inlerred extent of lahars in vicinity of Redoubt Volcano. Most lahal cleposits may have originated high up sn the volcano, at the head of the tributary yallev marlied by an asterisk, 
thinner in the narrow linear valleys (cf, Crandall, 1971, p. 7). The total area inferred to be underlain by lahar deposits is about $87 \mathrm{~km}^{2}$. At a conservative figure of $5 \mathrm{~m}$ for the average thickness, a minimum estimate of the volume is $435 \times 10^{6} \mathrm{~m}^{3}$. This estimate may be in error by an order of magnitude, but it serves to emphasize the enormous size of the deposits.

Photointerpretation suggests the lahars originated at the head of one, and possibly all Cour, tributary valleys that drain the summit. region of Redoubt Volcano southwest to the North Fork of Crescent River (fig. 1). Glaciers occupy three of these four valleys. Three of the four fans formed at the mouths of the tributary valleys have coalesced on the floor of North Fork valley. The fan of the tributary shown by an asterisk (fig. 1) is dissected by stream erosion, and exposes several meters of poorly sorted material comprising two distinct beds. On the basis of brief examination, we tentatively interpret the exposed materials as lahar deposits. Beeause this fan is also by far the largest of the four-in fact, displacing the North Fork to the far valley wall-we infer that this particular tributary valley may have been the principal source of the Crescent River lahars.

The original seaward extent of the lahar deposits is unknown. Large blocks of fresh andesite, similar to blocks in the lahar deposits exposed in the sea clifrs, occur in the intertidal zone off the mouth of the Crescent River. The seaward extent of these blocks has not been mapped, but the deposits have certainly been re. duced from their original extent by marine erosion.

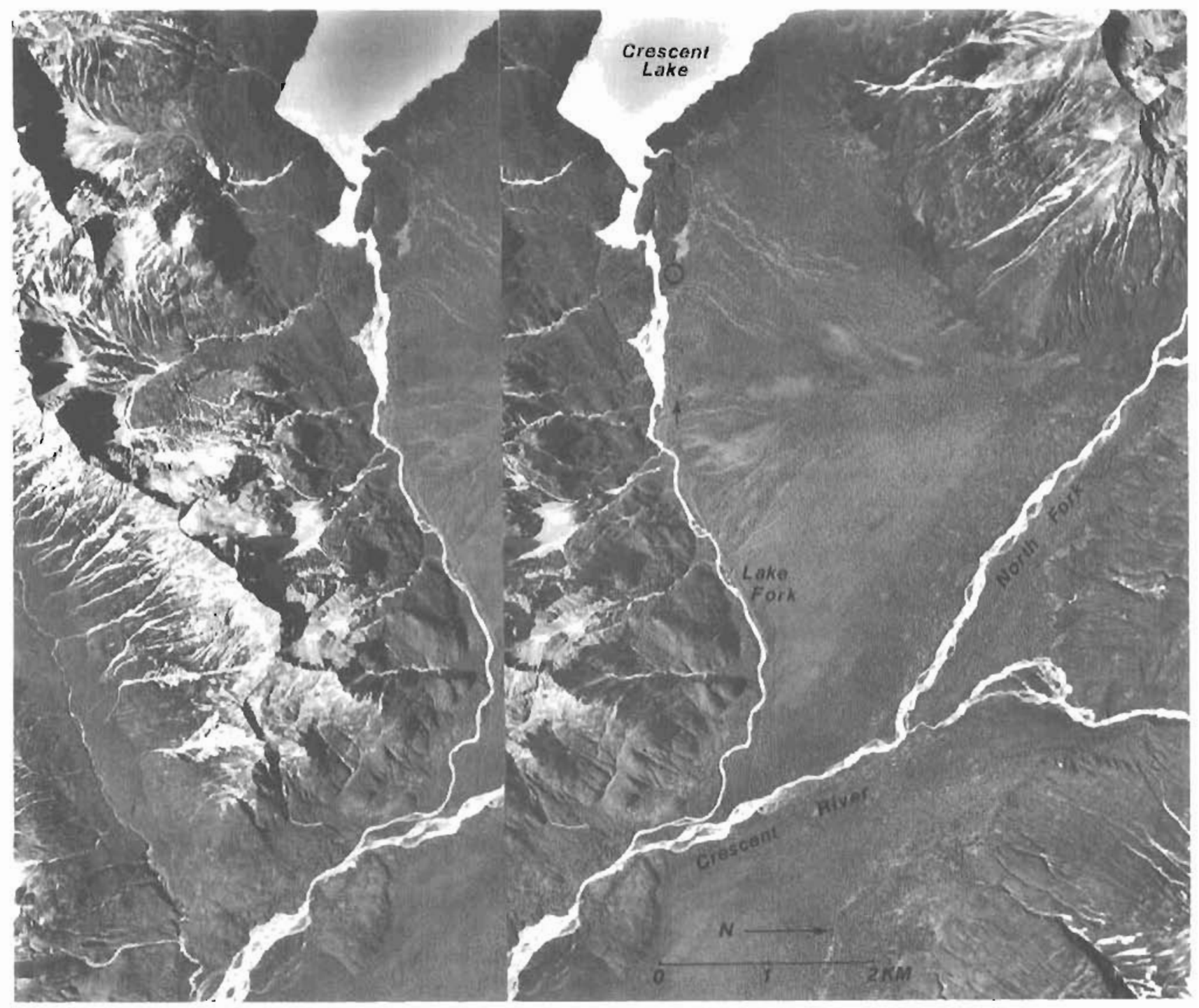

Figure 2. Stereo pair showing morphology of lahar fan north of Lake Fork of Crescent River. Low mounds between arrows are probably piles of large blocks deposited by lahars. Note relict radial channels and apparen $t$ absence of active surface drainage. Radiocarbon sample was collected from crest of circled mound (fig. 1). U.S. Geological Survey photos M 4H54-125 and -126, August 29, 1954. 
An interesting geomorphic feature in figure 2 is a series of low mounds, from 15 to $60 \mathrm{~m}$ across and up to $15 \mathrm{~m}$ high, along the banks of the Lake Fork of the Crescent River. At the lop of one mound we observed $45 \mathrm{~cm}$ of alternating layers of light ash and dark organic. rich ash atop a lahar deposit, which we excavated to a depth of $75 \mathrm{~cm}$.

\section{INTERNAL CHARACTERISTICS}

Deposits of at least two individual lahars are exposed in 10-m-high sea cliffs along Cook Inlet (fig. 3). The thickness of each lahar deposit is from 1 to $3 \mathrm{~m}$. Stratified fluvial sediments make up only a minor part of the material exposed in the sea cliffs. Up to $1 \mathrm{~m}$ of Muvial sediments crops out beneath the lowermost lahar deposit at most locations; other lahar deposits may exist at depth. Stratified deposits between or atop exposed lahar deposits comprise thin sheets or lenses rather than cut-and fill channel deposits. Such stratified deposits may have formed during the final stages of lahar activity when some flushing of fines by internal drainage may bave occurred.

Lahar deposits exposed in the sea cliffs are nonsorted and internally massive. Largest clasts are about $1 \mathrm{~m}$ in maximum dimension, but most of the coarse clasts are less than $0.75 \mathrm{~m}$. Coarse clasts are predominantly fresh porphyritic andesite; a few are equigramular and composed of plutonic rocks of the Aleutian Range batholith (Detterman and others, 1976) on which Redoubt Volcano is constructed. There is an upward decrease in the mean size of cobbles and largex clasts within individual deposits (inset, fig. 3), and a quick point count suggests that the abundance of pebble and larger clasts decreases from about 40 percent at the bottom to about 20 percent at the top. X-ray diffrac. tion analyses of the fine fraction from two lahar samples identify mainly plagioclase and homblende with little clay or chlorite. Thus, the lahar material apparently is derived from fresh flows and volcanic ash. We have no data to indicate that hydrothermal alteration products are present in significant amounts.

The size distribution of the fine part of a Crescent River lahar deposit compares closely with size distributions of Mount Rainier lahar deposits and tilf (fig. 4). Bull (1964) used sorting coefficient, phi-standard deviation, and phi-quartile deviation to classify alluvial fan deposits into waler-laid, mudflow, and intermediate categories. Our grain-size analyses fall into Bull's mudflow category according to all three parameters; the sand-sized-and-finer fraction is greater than 50 percent (at least at the top of the lahar deposits).

A tilted block of stratified sand and gravel occurs midway between Polly Creek and Crescent River (fig. 5). The steep dip and absence of an obvious channel in the surface of the lahar deposit suggest that the block is an accidental inclusion of prelahar fluvial sediments in the lahar deposit. A sand dike in the block suggests that the block tailed brittlely while the enclosing lahar was still fluid.

Airfall ash layers locally underlie the upper and lower lahar deposits. Near the mouth of Crescent River, for example, $1 \mathrm{~cm}$ of medium-to-coarse sand-sized ash underties the upper lahar deposit. Beneath the ash, up to $1 \mathrm{~m}$ of laterally discontinuous, stratified sand and gravel overlies another lahar deposit.

We have no data that bear specifically on the temperatures of emplacement. Colors of the lahar deposits are purple gray and red brown. At one locality $6 \mathrm{~cm}$ of red-brown sand and sill occur belween an ash layer at the base of the lower lahar deposit and above crossbedded fluvial sediments. The red-brown color may be due to heating by the lahar or it may be primary. Wood fragments in the lower, purple-gray lahar deposit have a thin black rind, which may be carbon produced by postdepositional oxidation or by heat during emplace. ment.

Lahar deposits were examined at only three inland localities. Observations at the tributary fan on the North Fork and in a pit excavated in a mound near Crescent Lake have been previously discussed. The third locality is a riverbank exposure about $1 \mathrm{~km}$ upstream from the confluence of Lake Fork and North Fork (fig. 1). Four individual beds, each from 1 to $2 \mathrm{~m}$ thick, compose most of the 9-m-thick exposure. Three beds are mixtures of pebbles and cobbles with some sand and boulders; the fourth bed is about 80 percent pebbles, cobbles, and boulders and 20 percent silty sand. The largest clast observed in place was about $1 \mathrm{~m}$ in maximum dimension, but clasts as large as $2 \mathrm{~m}$ were observed nearby on the modern flood plain. Vertical size gradation of larger clasts was not apparent. These deposits differ Prom those exposed in the sea cliffs in their coarser matrix, their lack of obvious vertical size gradation, and their apparent lack of interbedded, well-stratified fluvial deposits or ash. Either the differences in the riverbank exposure are due to lateral variations within the lahar deposits, or the deposits simply do not correlate with those exposed in sea cliffs.

\section{INTERPRETATION OF OBSERVATIONS}

On the basis of grainsize distribution (lig. 4), the Crescent River deposits exposed in sea cliffs may be classified as mudflows. As flgure 4 shows, the deposits also resemble till; however, the distinction between till and lahar deposits cannot be made solely on the basis of grain-size distribution. For example, Crandall (1971, figs. 3 and 11) reports size distributions of till from Mount Rainier that are similar to nearby deposits of the Osceola Mudflow, a lahar.

Features other than grain-size distribution support the inierence that the Crescent River deposits are lahars rather than till. Fixst, upward fining has been noted in latiar deposits elsewhere and Crandall (1971, p. 6) suggests that such vertical gradation aids in 


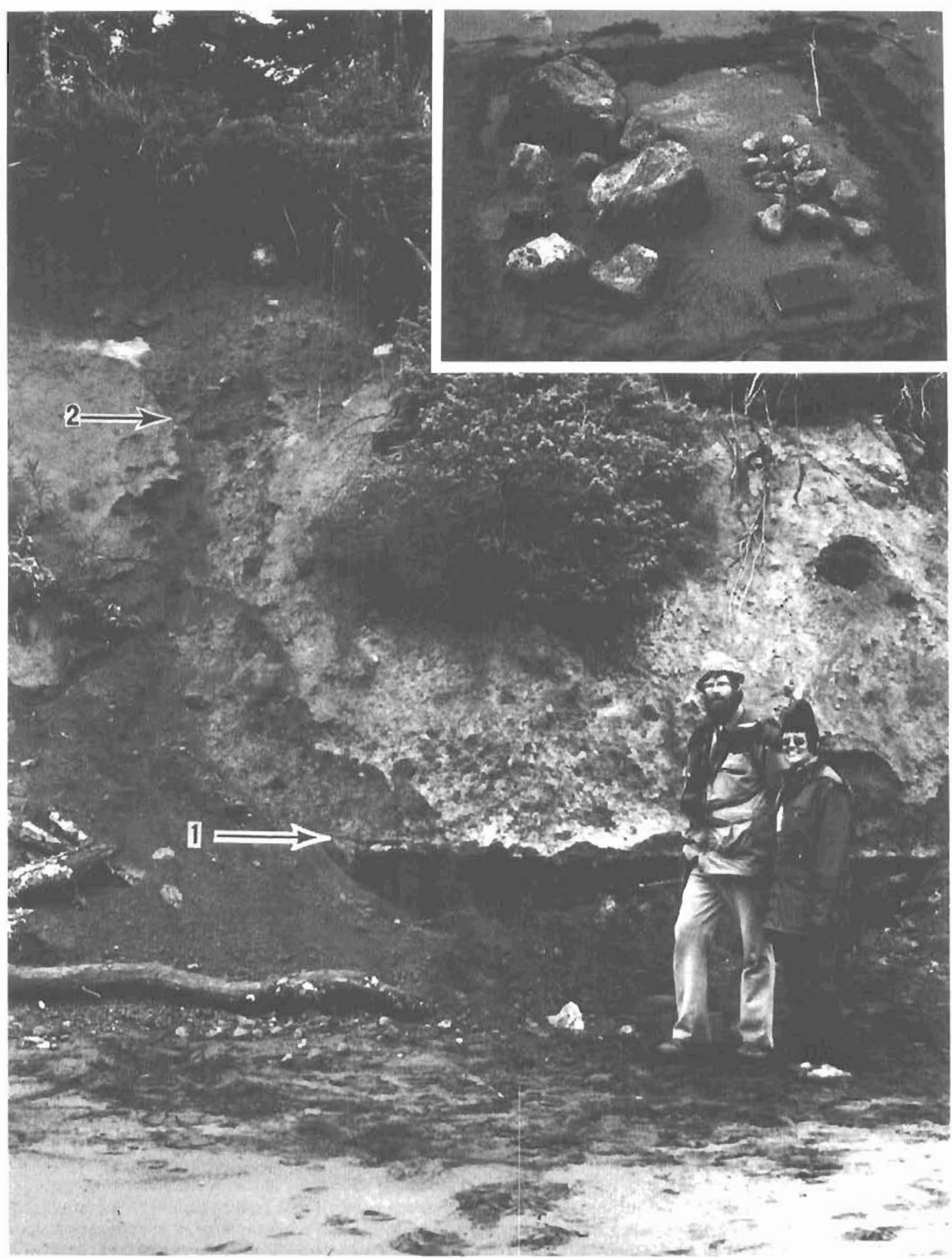

Figure 3. Lahar deposits exposed in sea cliffs $6 \mathrm{~km}$ northeast of mouth of Crescent River. Base of lowest exposed lahar (1) and contact between lower and upper lahars (2) nre marked. Suratified alluvium underlies lahars, but is separated from them by soil horizon (1). Inset shows size variations of representative clasts from bottom (left) and top (right) of lower exposed lahar (field notebook gives scale). 


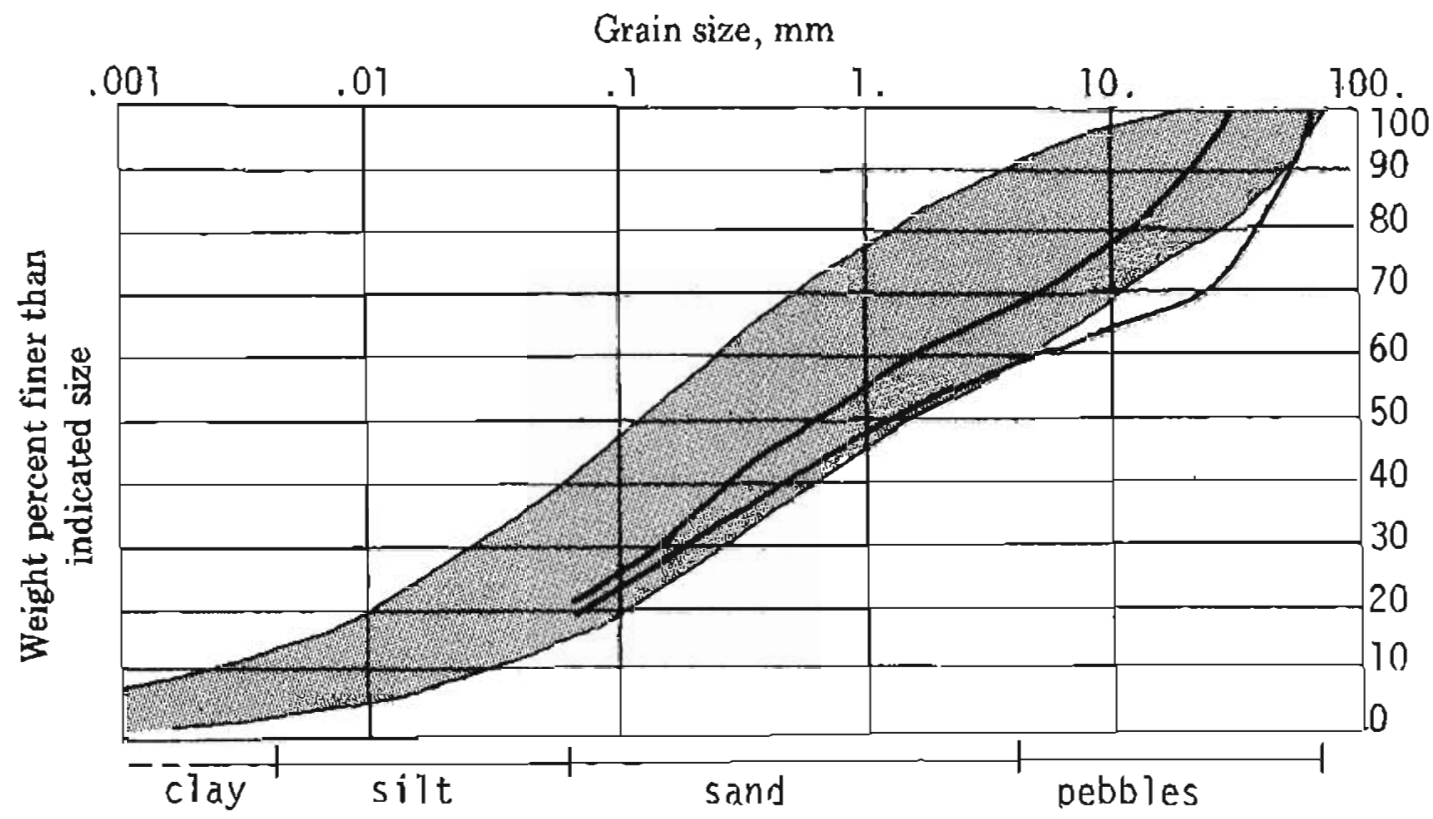

Figure 4. Solid lines are cumulative size distributions of two sea-clifl samples from Crescent River lahars. Shaded matrix. envelope represents size distributions of eight samples of Osceola Mudflow and three samples of Evans Creek tiłl, Mount Rainier (Crandall, 1971, figs. 3 and 1J).

distinguishing lahars from till. Second, it is difficult to imagine that the ash that commonly underles - the Crescent River deposits would not have been eroded by glaclers depositing the overlying till, Ash layers are reported to underlie lahar deposits elsewhere and they indicate the inability of mudnows to erode during passage (Crandall, 1971, p. 8). Third, the age of the deposit (about $3,500 \mathrm{yr}$ ) is probably too young for till. Moraines correlated with the Tustumena Stade occur from 2.4 to $4.5 \mathrm{~km}$ beyond present valley glaciers in the Iniskin-Tuxednl region south of the Crescent River (Detterman and Hartsock, 1966). The Tustumena Stade on the east side of Cook Injet ranges from about A.D. 200 to about 3500 B.C. (Karistrom, 1964). The nearest valley glacier is more than $20 \mathrm{~km}$ from the Crescent River deposits at the coastline, and it is highly improbable that Tustumena-age advances of Crescent Valley glaciers reached the coastline.

The origin of the mounds mear Crescent Lake is uncertain. If the preceding arguments are accepted as prool of the laharic origin of the deposits, then the mounds must be similar to one of two types of mounds found in lahar deposits elsewhere. One type consists of large blocks of rock, commonly veneered by fine lahar material. These blocks are prohably deposited in an initial rush of the lahar, and the finer material subsequently drains downvalley so that the surface adjacent to the blocks is lowered. Such block-cored mounds on Mount Rainier are up to $120 \mathrm{~m}$ across and $30 \mathrm{~m}$ high (Crandall, 1971). Anolher type of mound is thought to result from extrusion of fluid material from within a lahar through fractures in a desiccated upper surface.
Such mounds are described by Mason and Foster (1956), who attribute extrusion to hydrostatic pressure where the lahar comes to resl on an inclined prelahar surface. These extrusion mounds are from 10 to $60 \mathrm{~m}$ high and from 75 lo $600 \mathrm{~m}$ across. Although we found no blocks within $75 \mathrm{~cm}$ of the surface of one mound at Crescent Lake, such blocks could be more deeply buried beneath finc lahar material. On the basis of their sizes, we prefer a block-pile origin for the Crescent River mounds.

\section{AGE OF THE LAHARS}

We have uncorrected ages of $3,450 \pm 140,3,560 \pm$ 160 , and $3,605 \pm 145$ radiocarbon $y^{6}{ }^{6}$ for three different wood fragments collected from the lower lahar deposit in a sea-cliff exposure about $6 \mathrm{~km}$ east of the Crescent River (Tigs. 1 and 6). Each wood fragment had a carbon rind several milsimeters thick but did nol appear to be internally carbonized. At the sample locality the upper lairar deposit rests directly on the lower lahar deposit, and there is no apparent weathering profile at the top of the lower deposit (fig. 6). One lahar apparently followed the other closely in time.

Near the sample locality the upper lahar deposit is overlain by soil, peat, and ash. Six distinct layers of aixfall ejecta occur in the lower part of the section (fig. 6). Although we have no data on rates of peat accumulation at the site, the presence of more than $40 \mathrm{~cm}$ of peat and

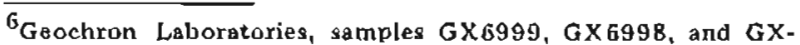
5771 , respectively.
} 
organic soil above the upper lahay deposit is consistent with an apparent lahar age of about $3,500 \mathrm{yr}$. A single uncorrected age of $3,295 \pm 135$ radiocarbon $\mathrm{yr}^{7}$ for peat overlying the upper lahar supports an age of $3,500 \mathrm{yr}$.

${ }^{7}$ Geachion Letboratories, Simple GX7000
A sample from the lon of a lahar mound near the outlet of Crescent Lake (iips. $\perp$ and 2) gave a single uncorrected atge of 2,955 ․ 130 radiocarbon $\mathrm{yr}^{\mathrm{B}}$. The sample was à tine, darik-gray to black organic soil underlain by $2 \mathrm{~cm}$ of white-gray ash that is in turn underlain by a diamiclon. We infer that the diamicton is part of the Crescent River lahar deposit.

${ }^{B}$ Geochron Laboratories, sample $6 \mathrm{x}$; $00 \mathrm{u}$.

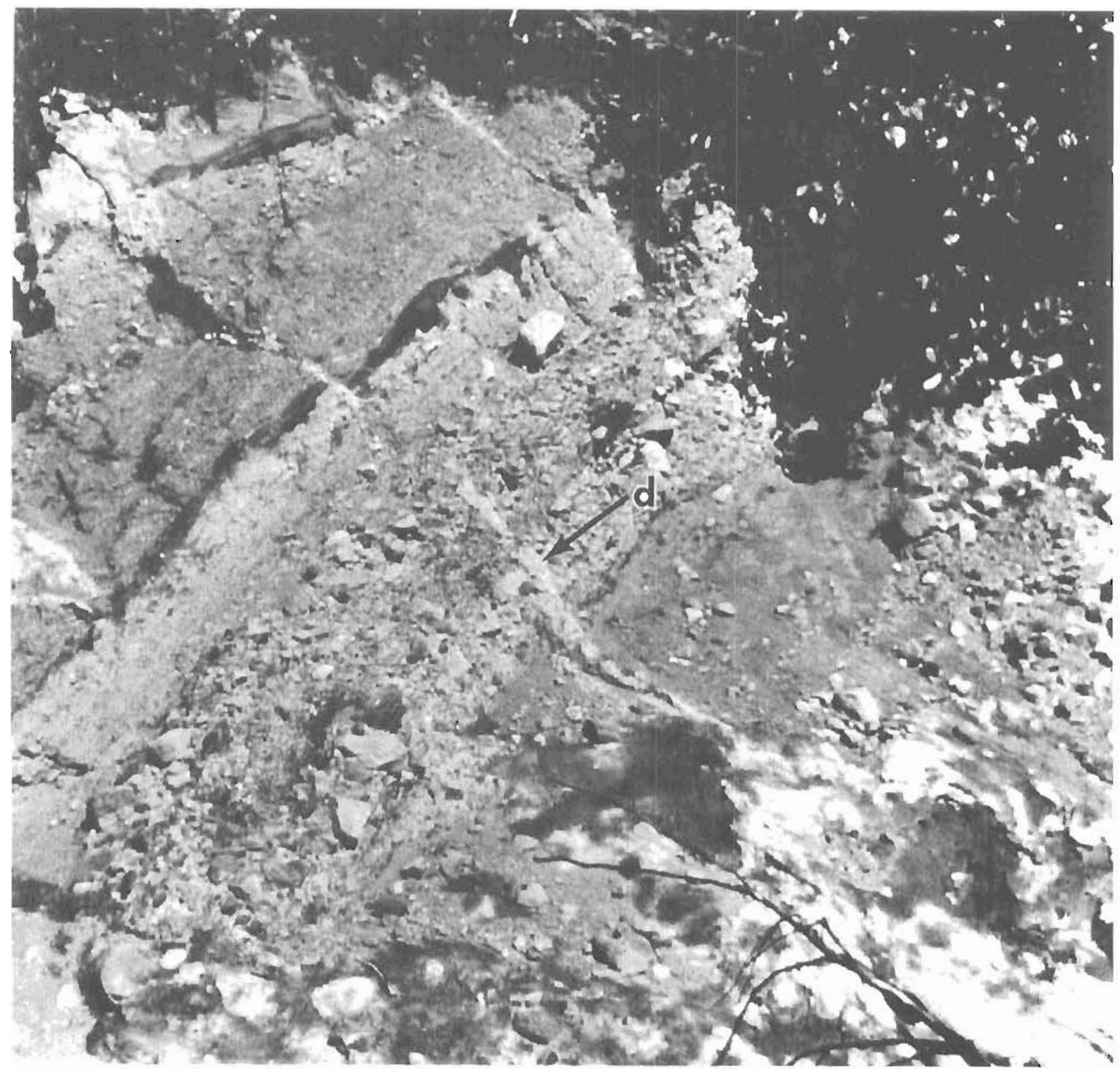

Figure 5. Inclined block of stratified sand and gravel enclosed in lahar material in sea cliffs about $4 \mathrm{~km}$ northeast of mouth of Crescent River. Sand dike (d) is marked. Tolal exposed width of block is about 2 m. Photcol's.|h by M.D. Howland, June 1978 . 


\section{ORIGIN OF THE LAHARS}

On the basis ol available data, we speculate on a possible scenario for the origiln of the Crescent River lahars. At least two lahars, each preceded by deposition of airfall ash, are documented in the sca-cliff exposures. At one locality a thin basal ash layer overlying alluvium indicates lihat an ash eruption closely preceded laliar deposition. In lact, the lahars were probably triggered by eruptive activity.

The apparent brittle failure of the block of sediment shown in figure 5 suggests that the block was frozen at the time of transport. If so, then the triggering eruption must have occurred during wincer or early spring. Such conditions are similar to those at the time of the Drift River flooding during the winter of 1965-66. On January 25 and February 9, 1966, two flash floods with fronts as high as 4.5 to $6 \mathrm{~m}$ occurred on the Drift River (fis. 1). 'The first carried ice blocks described "as big as a D.7 Cat"; the second flood was apparently ice free."

The Jamuary 25, 1966 flood was keported in lle Junuary 26. 1966 cdition of line Farbanks Dajly New5-Miner. The article moneioned llad it seismalogical crew was rescued from the food plain of the Drift River. The second fluod was inentioned


in a 1966 celephone conversalion uith Dr. R.B. Farlyes. Grombsical Insticule, Universily of Alaska, Fuirbanks.



Lahar deposit, red-brown

Lahar deposit, purple-gray; includes wood fragments

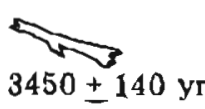

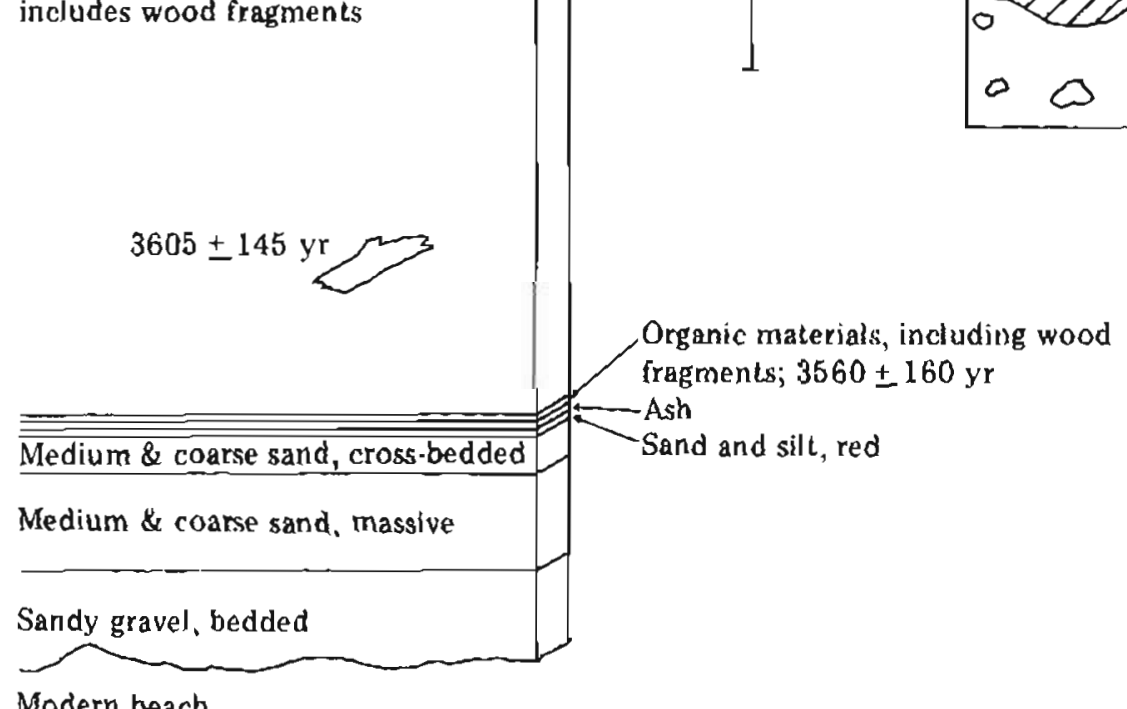

Figure 6. Generalized stratigraphic section at location of sca-cliff madiocartron samples (fig. 1). Radiocarbon ages arc uncorrected. 
Flooding was probably caused by a sudden release of meltwater from the summit crater; at the same time one or more lahars flowed down the north flank of the volcano onto the Drift River flood plain (Post and Mayo, 1971; Miller, 1973). The 1966 lahars occurred in the same location as older lahars, which built a large cross-valley fan adjacent to an unnamed glacier on the Drift River flood plain (fig. 1). All lahars apparently came irom the summit crater, which is breached to the north, and followed the glacial trough down into the Drift River valley. Snow and glacial ice are probably the sources of water involved in the lahars.

In the case of the Crescent River lahars, heat may have been provided by airfall ejecta, lava, subglacial heating, or all three. The presence and lithologies of large blocks in the mounds near Crescent Lake should be confirmed because very large blocks require a rock slide or fall for their origin, which could be related to a specifie source area and process.

\section{POTENTIAL HAZARDS OF LAHARS}

In recent years destructive iahars have been responsible for about 40 percent of the casualties from volcanic eruptions (Williams and McBimey, 1979, p. 350). Destruction by lahars, is partly due to their rapid movement and lack of advanced warning.

Velocities of very fluid lahars on steep slopes are as high as 80 to $100 \mathrm{~km} / \mathrm{hr}$; velocilles on gentle slopes are generally less. Another characteristic contributing to the destructive nature of lahars is their tendency to flow in valleys where they can travel great distances. The Crescent River lahars, although large, are hardly comparabie to some of those of Mount Rainler, which traveled more than $100 \mathrm{~km}$.

Also, the surface of the lahar during flow is commonly higher than the surface of the resulting deposit. Presumably, the elevation of the lahar surface decreases where it spreads from a narrow valley outward into a fan. Thus, the present average thickness of individual lahar deposits exposed in sea cliffs near the Crescent River is less-by an unknown amount-that it was during Row.

The potentlal hazard posed by future lahars in the Crescent River valiey is difficult to estimate quantitatively. Present human liabitation consists of a small number of dwellings along the coastline. The lahars we studied may not be the only ones that reached the constline. Others may be buried at depth.

An assessment of hazards due to lahars requires delailed field studies of the entire volcano. Historic lahar activity has been confined to the Drift River valley on the north side of the volcano. However, voluminous deposits provide evidence of significant lahar activity on the south side during Holocene time.

\section{ACKNOWLEDGMENTS}

A preliminary survey of the lahar deposits was carried out in June 1978 as part of a field project to assess geologic processes and resources of the coastal 7.one. Other members of the 1978 field party were Mark Howland and Chad Price (DGGS) and Bruce Molnia (USGS). We thank these workers for their contribulions and discussions in the field. The 1979 and 1980 field parties were supported by the Bureau of Land Management through an interagency ogreement with the National Oceanic and Atmospheric Administra. tion, under which a multiyear program responding to the needs of petraleum development of the Alaskan Continental Shell is managed by the OCSEAP office (Contract number 03-5-022-55, Task 2).

Constructive comments on an early version of this manuscript were made by Mark Howland, Randall Updike, and Thomas Milier. The final version was revlewed by Richard Reger and Wyatt Gilbert and edited by Frank Larson. We thank these readers for their contributions.

\section{REFERENCES CITED}

Beaglehole, J.C., 1967, The journals of Captain James Cook on his voyages of discovery, III: The voyage of the Resolution and Discovery, 1776-1780: Cambridge, Cambridge Univ. Press, $370 \mathrm{p}$.

Beverage, J.P., and Culbertson, J.K., 1964, Hyperconcentrations of suspended sediment: Jour. Hydraulics Div., Proc. American Soc. Civil Engineers, v. 90, no. HY $_{6}, 9,117-28$.

Bull, W.B., 1964, Alluvial lans and near-surlace subsidence in western Fresno County, California: U.S. Geol. Survey Prof. Paper 437-A, 71 p.

Coats, R.R., 1950, Volcanic activity in the Aleutian arc: U.S. Geol. Survey Bull. 974-B, p. 35-49.

Crandall, D.R., 1971, Postglacial lahars from Mount Rainier Volcano, Washington: U.S. Geol. Survey Prol. Paper 677, $75 \mathrm{p}$.

Detterman, R.L., and Hartsock, J.K., 1966, Geology of the Iniskin-Tuxedni region, Alaska: U.S. Geol. Survey Prof. Paper 512, $78 \mathrm{p}$.

Detlerman, R.I., Hudson, Travis, Plafker, George, Tysdal, R.G., and Hoare, J.M., 1976, Reconnaissance geologic map along Bruin Bay and Lake Clark [aults in Kenai and Tyonek Quadrangles, Alaska: U.S. Geol. Survey Open-file Rept. 76-477, 4 p.

Karlstrom, T.N.V., 1964, Quaternary geology of the Kenai Lowland and glacial history of the Cook Inlet region, A.laska: U.S. Geol. Survey Prof. Paper $443,69 \mathrm{p}$.

MacDonald, G.A., 1972, Volcanoes: Englewood Clirfs, N.J. Prentice Hall, $510 p$.

Mason, A.C., and Foster, H.L., 1956, Extruded mudllow hills of Nirasaki, Japan: Jour. Geology, v. 64, p. $74-83$. 
Miller, T.P., 1973, Evaluation of Redoubt Volcano for designation as a Registered Natural Landmark: Unpublished report on file at Branch of Alaska Geology, U.S. Geol. Survey, Anchorage, Alaska, 7 p.

Post, Austin, and Mayo, L.R., 1971, Glacier-dammed lakes and outburst floods in Alaska: U.S. Geol. Sur. vey Hydrol. Inv. Atlas HA-455.

Rodine, J.D., 1975, Analysis of the mobilization of debris flows: Stanford, Stanford Univ., CA, Ph.D. thesis, $225 \mathrm{p}$.

Sharp, R.P., and Nobles, L.H., 1953, MudPlow of 1941 at Wrightwood, southern California: Geol. Soc. America Bull, v. 64, no. 5. p. 547-60.

van Bemmelen, R.W.. 1949, The geology of Indonesia, v. 1A: General geology of Indonesia and adjacent archipelagoes: The Hague, Govt. Printing Office, $732 \mathrm{p}$.

Varnes, D.J., 1958, Landslide types and processes, in Eckel, E.B., ed., Landslides and engineering practice: Washington, D.C., National Research Council Highway Research Board Spec. Rept. 29, p. 20-47.

Williams, Howel, and McBirney, A.R., 1979, Volcanology: San Francisco, Freeman Cooper and Co., 397 p.

Wilson, C.R., and Forbes, R.B., 1969, Infrasonic waves from Alaskan volcanic eruptions: Jour, Geophys. Research, v. 74, no. 18, y. 4511-22.

Wilson, C.R., Nichparenko, S., and Forbes, R.B., 1966. Evidence for two sound channels in the polar atmosphere from infrasonic observations of the eruption of an Alaskan volcano: Nature, v. 211 , p. 163.65. 